\title{
Short-lived pollutants in the Arctic: their climate impact and possible mitigation strategies
}

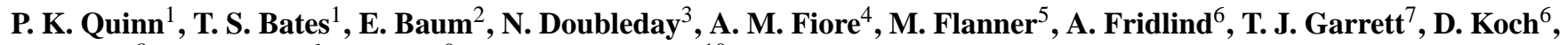 \\ S. Menon ${ }^{8}$, D. Shindell ${ }^{6}$, A. Stohl ${ }^{9}$, and S. G. Warren ${ }^{10}$ \\ ${ }^{1}$ NOAA Pacific Marine Environmental Laboratory, Seattle, WA, USA \\ ${ }^{2}$ Clean Air Task Force, Boston, MA, USA \\ ${ }^{3}$ Carleton University, Ottawa, ON, Canada \\ ${ }^{4}$ NOAA Geophysical Fluid Dynamics Laboratory, Princeton, NJ, USA \\ ${ }^{5}$ Advanced Study Program, NCAR, Boulder, CO, USA \\ ${ }^{6}$ NASA Goddard Institute for Space Sciences, New York, NY, USA \\ ${ }^{7}$ University of Utah, Salt Lake City, UT, USA \\ ${ }^{8}$ Lawrence Berkeley National Laboratory, Berkeley, CA, USA \\ ${ }^{9}$ Norwegian Institute for Air Research, Kjeller, Norway \\ ${ }^{10}$ University of Washington, Seattle, WA, USA
}

Received: 17 October 2007 - Published in Atmos. Chem. Phys. Discuss.: 9 November 2007

Revised: 13 February 2008 - Accepted: 27 February 2008 - Published: 25 March 2008

\begin{abstract}
Several short-lived pollutants known to impact Arctic climate may be contributing to the accelerated rates of warming observed in this region relative to the global annually averaged temperature increase. Here, we present a summary of the short-lived pollutants that impact Arctic climate including methane, tropospheric ozone, and tropospheric aerosols. For each pollutant, we provide a description of the major sources and the mechanism of forcing. We also provide the first seasonally averaged forcing and corresponding temperature response estimates focused specifically on the Arctic. The calculations indicate that the forcings due to black carbon, methane, and tropospheric ozone lead to a positive surface temperature response indicating the need to reduce emissions of these species within and outside the Arctic. Additional aerosol species may also lead to surface warming if the aerosol is coincident with thin, low lying clouds. We suggest strategies for reducing the warming based on current knowledge and discuss directions for future research to address the large remaining uncertainties.
\end{abstract}

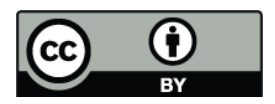

Correspondence to: P. K. Quinn (patricia.k.quinn@noaa.gov)

\section{Introduction}

Arctic temperatures have increased at almost twice the global average rate over the past 100 years (IPCC, 2007). Warming in the Arctic has been accompanied by an earlier onset of spring melt, a lengthening of the melt season, and changes in the mass balance of the Greenland ice sheet (Stroeve et al., 2006; Zwally et al., 2002). In addition, Arctic sea ice extent has decreased from 1979 to 2006 in every month (Serreze et al., 2007). During the 2007 melt season, Arctic sea ice dropped to the lowest levels observed since satellite measurements began in 1979, resulting in the first recorded complete opening of the Northwest Passage (NSIDC, 2007). Impacts of ice loss include reduction of the Earth's albedo, a positive feedback which leads to further warming. The earlier onset of spring melt is of particular concern as this is the season of maximum snow-albedo feedback (e.g., Hall and Qu, 2006). Timescales for a collapse of the Greenland ice sheet and a transition to a seasonally ice-free Arctic are highly uncertain, as are the regional and global impacts. However, clear ecological signals of significant and rapid response to these changes within the Arctic are already present. For example, paleolimnological data from across the Arctic have recorded striking changes in diatoms and other bioindicators corresponding to conditions of decreased ice cover and warming (Smol et al., 2005). Circumpolar vegetation also is showing signs of rapid change, including an expansion of shrub and tree coverage (Chapin et al., 2005). 


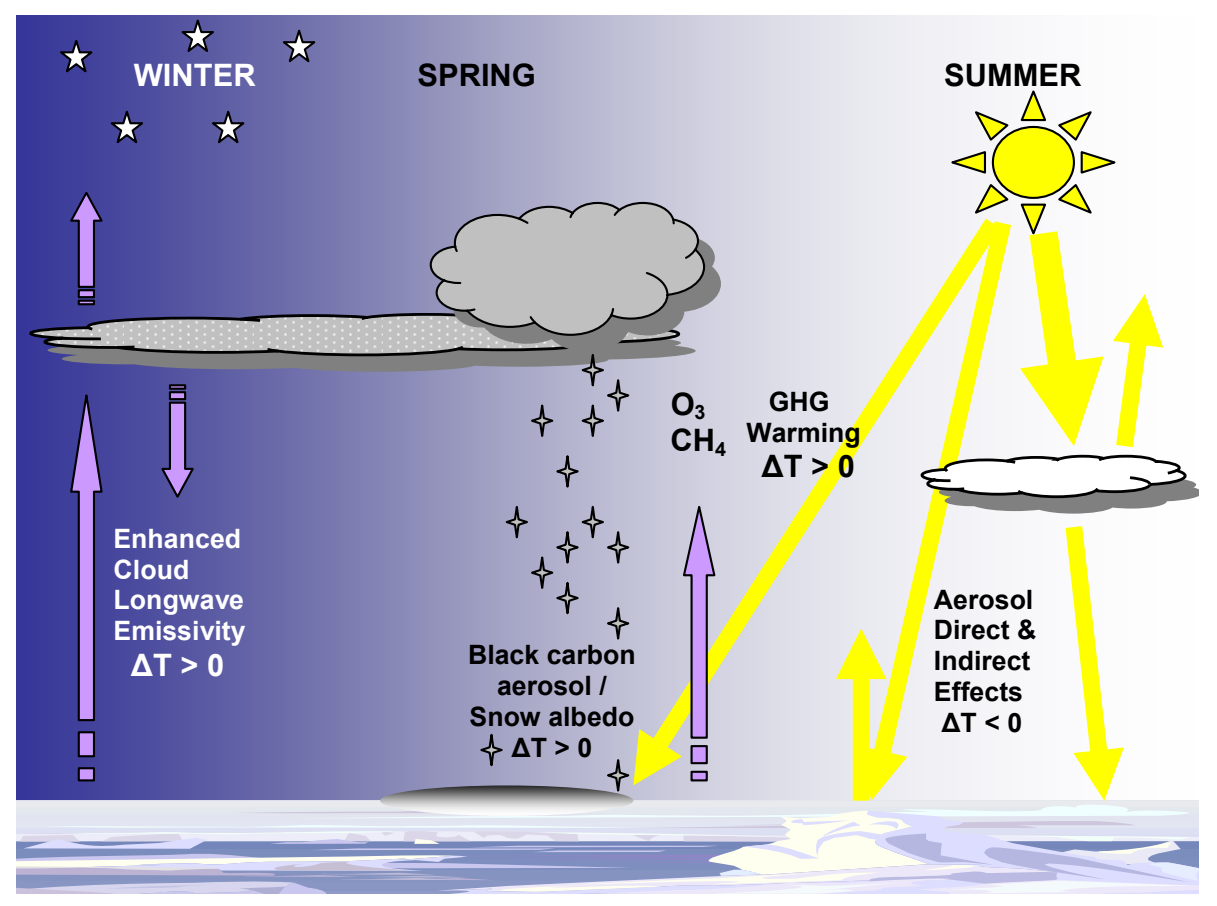

Fig. 1. Forcing mechanisms in the Arctic environment resulting from the poleward transport of middle latitude gas and particulate phase pollutants. Season of maximum forcing at the surface $\left(F_{S}\right)$ is indicated for each forcing agent. $\Delta T$ indicates the surface temperature response.

Arctic warming is primarily a manifestation of global warming, such that reducing global-average warming will reduce Arctic warming and the rate of melting (IPCC, 2007). Reductions in the atmospheric burden of $\mathrm{CO}_{2}$ are the backbone of any meaningful effort to mitigate climate forcing. But even if swift and deep reductions were made, given the long lifetime of $\mathrm{CO}_{2}$ in the atmosphere, the reductions may not be achieved in time to delay a rapid melting of the Arctic. Hence, the goal of constraining the length of the melt season and, in particular, delaying the onset of spring melt, may best be achieved by targeting shorter-lived climate forcing agents, especially those that impose a surface forcing that may trigger regional scale climate feedbacks pertaining to sea ice melting. Addressing these species has the advantage that emission reductions will be felt immediately. The large uncertainties associated with parameterizing the forcing and temperature response due to these pollutants prevent us from providing definitive answers regarding impacts and mitigation strategies. We can, however, focus attention on the issues involved, provide a "state-of-the-art" review, and make initial estimates of the forcing and response due to each pollutant. The forcing agents included in this discussion are methane, tropospheric ozone, and tropospheric aerosols. In this article we describe the mechanisms by which these shortlived pollutants impact Arctic climate (Fig. 1) and present the first seasonally averaged forcing and temperature response estimates for the Arctic. In addition, we outline near-term climate mitigation opportunities for the Arctic and suggest areas of future research.

\section{Short-lived pollutants that impact Arctic climate}

\subsection{Methane}

Since the industrial revolution, rapid increases in human activity have led to more than a doubling of atmospheric methane concentrations (Wuebbles and Hayhoe, 2002). A combination of ice core records and atmospheric measurements has revealed that methane levels, at $\sim 1770 \mathrm{ppbv}$, are higher now than at any time in the past $650 \mathrm{kyr}$ (Petit et al., 1999; Spahni et al., 2005). Growth rates have slowed over the last few decades with current observations indicating that methane levels are either leveling off or starting to increase after a brief decline in the early 1990s (Dlugokencky et al., 2003). At the same time, growth rates are becoming more variable. Reasons for the change in growth rates are not well understood beyond the acknowledgement of a change in the balance between sources and sinks (IPCC, 2001).

Anthropogenic sources, which account for about two thirds of emitted methane, include coal and gas production and use, rice cultivation, agriculture and waste disposal, biomass burning, landfills, and animals in the form of solid waste and enteric fermentation (e.g., Kirchgessner, 2000; Huang et al., 1998; Harper et al., 1999; Houweling et al., 1999; Johnson et al., 2000). The largest single source of methane is natural wetlands (IPCC, 2001) with wetlands north of $60^{\circ} \mathrm{N}$ responsible for about $13 \%$ of the global natural methane flux (Cao et al., 1998). Measurements in the sub-Arctic and Arctic over the past decade have indicated 
that methane emissions from these regions are increasing due to increasing temperatures and the resulting disappearance of permafrost and wetter soil conditions (e.g., Nakano et al., 2000; Zimov et al., 2006). Permafrost and vegetation changes in one region in sub-Arctic Sweden have led to 20 to $70 \%$ increases in local methane emissions between 1970 and 2000 (Christensen et al., 2004). In Arctic regions of continuous permafrost, warming has resulted in a degradation of permafrost and an increase in the size and number of thaw lakes. It has been estimated that this increase in lake area has led to a $58 \%$ increase in methane emissions (Walter et al., 2006). Further warming in Siberia could result in thousands of teragrams of methane being emitted from the 500 gigatons of labile $\mathrm{C}$ that is currently stored in regional permafrost. (By comparison, the atmosphere now contains 5000 teragrams of methane.).

With a lifetime of about 9 years (Prinn et al., 1995), methane is much shorter lived than $\mathrm{CO}_{2}$ but still is globally well-mixed. Methane has contributed the second largest anthropogenic radiative forcing since the pre-industrial after $\mathrm{CO}_{2}$ and, on a per molecule basis, is a more effective Greenhouse Gas (GHG) (IPCC, 2001). Radiative forcing by methane results directly from the absorption of longwave radiation and indirectly through chemical reactions that lead to the formation of other radiatively important gases (Wuebbles et al., 2002). The latter is dominated by the formation of tropospheric ozone, also a short-lived GHG, through the oxidation of methane by the hydroxyl radical $(\mathrm{OH})$ in the presence of nitrogen oxides $\left(\mathrm{NO}_{\mathrm{x}}\right)$ and sunlight.

\subsection{Tropospheric ozone}

Both observations and modeling studies provide evidence that tropospheric ozone concentrations, which are controlled primarily by photochemical production and loss processes within the troposphere, have increased since preindustrial times due to increases in emissions of anthropogenic ozone precursors (Oltmans et al., 1998). The rapid increase in ozone concentrations during the latter half of the 20th century has been attributed to increases in economic development at middle and low latitudes (Shindell et al., 2006). Ozone precursors include $\mathrm{NO}_{\mathrm{x}}$, carbon monoxide, methane, and non-methane volatile organic compounds (NMVOC) (Haagen-Smit, 1952; Seinfeld, 1988). Anthropogenic sources of these precursor gases include fossil fuel combustion and production, biofuel combustion, industrial processes, and anthropogenic biomass burning. Natural sources include wildfires, biogenic emissions from soils and vegetation, and lightning. In polluted air masses, ozone is formed primarily from rapid photochemical oxidation of NMVOCs in the presence of $\mathrm{NO}_{\mathrm{x}}$ (e.g., Chameides et al., 1992). In contrast, methane, being globally well-mixed, contributes to increases in background tropospheric ozone levels (Crutzen, 1973; Fiore et al., 2002; Dentener et al., 2005).
Changes in local tropospheric ozone affect Arctic climate by altering local radiation fluxes, while changes in both local and distant ozone amounts can modulate the transport of heat to the polar region (Shindell, 2007). The lifetime of ozone decreases during the summer in the extratropics since photochemical destruction rates increase with increasing insolation (Shindell et al., 2006). Hence, ozone that is produced in the northern hemisphere mid-latitudes is most efficiently transported to the Arctic in the non-summer months. Little is known about the contribution of local production of ozone and its precursors within the Arctic relative to extrapolar sources. Local sources include marine vessel emissions (Granier et al., 2006). Shipping emissions in the Arctic have the potential to increase Arctic ozone levels by a factor of 2 to 3 relative to present day.

Sub-Arctic and Arctic ozone precursor emissions may be increasing as boreal regions warm and forest fire frequency increases (Kasischke et al., 2005). Fires emit large quantities of $\mathrm{CO}$ and non-methane volatile organic carbon (NMVOC) compounds which may combine with anthropogenic emissions in the same region to produce large amounts of ozone. Generoso et al. (2007) showed that CO emissions from boreal fires in the spring and summer of 2003 made a substantial impact on concentrations in the Arctic. Agricultural fires may be particularly important sources to the Arctic, especially in eastern Europe and northern Asia as these are regions with very high fire frequency (Korontzi et al., 2006).

Record high concentrations of ozone were measured at the Zeppelin research station in Spitsbergen $\left(79^{\circ} \mathrm{N}\right)$ in April and May of 2006 (Stohl et al., 2007). This severe air pollution episode was a result of the combination of unusually high temperatures in the European Arctic and large emissions from agricultural fires in Belarus, Ukraine, and Russia. The high temperatures in the Arctic reduced the temperature gradient between the source and receptor regions, making lowlevel transport of pollution into the Arctic possible. Should the warming of the Arctic continue to proceed more quickly than that of the middle latitudes, transport from highly polluted source regions may become more frequent in the future, resulting in increased tropospheric ozone concentrations and a further increase in surface temperatures.

\subsection{Tropospheric aerosols}

Tropospheric aerosol concentrations in the Arctic are marked by a large increase each year in late winter and early spring (e.g., Shaw, 1995; Sirois and Barrie, 1999). The combination of intense isentropic transport from the mid-latitudes to the Arctic and strong surface-based temperature inversions that inhibit turbulent transfer (and, therefore, aerosol removal via deposition) results in this recurring phenomenon known as Arctic Haze (Iversen and Joranger, 1985; Klonecki et al., 2003). In addition, the dryness of the Arctic troposphere results in very little wet deposition during this time of year (Shaw, 1981). The dominant source regions for 
the haze include northern Europe and Asia with emissions of sulfate aerosol from fossil fuel combustion, nitrate from combustion of diesel and gasoline, and organic carbon and soot (black carbon) from fossil fuel, bio-fuel, and biomass combustion (Klonecki et al., 2003; Stohl, 2006). Long-term, ground-based measurements of sulfate and light scattering by aerosols show that, since the late 1970s, the highest recorded levels of Arctic Haze occurred in the 1980s and early 1990s (Quinn et al., 2007). Levels then decreased through the end of the 1990s primarily due to reductions in industrial emissions in the early years of the new Eurasian republics and, to a lesser extent, to more stringent power plant emission laws in the United States and Europe. More recent measurements indicate that levels of light scattering and black carbon may be increasing once again (e.g., Sharma et al., 2006). From 1980 to the present, nitrate concentrations have increased, suggesting that while power-plant sulfur emissions have decreased in the source regions to the Arctic, emissions from diesel and gasoline engines have increased (Quinn et al., 2007). The same agricultural fire event reported by Stohl et al. (2007) that resulted in anomalously high ozone also led to record high levels of aerosol optical depth and black carbon, indicating the potential impact of natural and prescribed episodic fires.

Tropospheric aerosols in the Arctic can perturb the radiation balance of the earth-atmosphere system in a number of ways (Quinn et al., 2007). Direct aerosol forcing occurs through absorption or scattering of solar (shortwave) radiation by aerosols. For example, a scattering aerosol over a low albedo surface will reflect incoming solar radiation, resulting in a cooling of the surface as well as the surface-atmosphere-aerosol column. An absorbing aerosol, such as one containing soot, over a highly reflective surface will result in a warming at altitudes above and within the haze layer and, instantaneously, a reduction of solar energy at the surface (Shaw and Stamnes, 1980). The added atmospheric heating will subsequently increase the downward longwave radiation to the surface, warming the surface. With the highly reflective surfaces typical of the Arctic springtime, even a moderately absorbing aerosol can lead to a heating of the surface-atmosphere-aerosol column. The Airborne Arctic Stratospheric Expedition (AASE) II flights in the winter of 1992 observed soot-containing aerosols at an altitude of $1.5 \mathrm{~km}$. Pueschel and Kinne (1995) calculated that this layer of aerosols could heat the earth-atmosphere system above a surface of high solar albedo (ice/snow) even for singlescattering albedos as high as 0.98 .

If hygroscopic pollution particles deliquesce and grow sufficiently large they may also impact the radiation balance in the Arctic by interacting with terrestrial (longwave) radiation (MacCracken et al., 1986). This forcing may be significant during the polar night when longwave radiation dominates the energy budget. Measurements made in the Arctic when the sun was below the horizon suggest that Arctic haze can have a detectable direct thermal radiative forcing by altering the flux of both downward and outgoing longwave radiation (Ritter et al., 2005).

Soot has an additional forcing mechanism when it is deposited to snow and ice surfaces (Clarke and Noone, 1985). Such deposition enhances absorption of solar radiation at the surface which can warm the lower atmosphere and induce snow and ice melting. Surface temperature responses are strongly linked to surface radiative forcings in the Arctic because the stable atmosphere of the region prevents rapid heat exchange with the upper troposphere (Hansen and Nazarenko, 2004). Measurements of BC and other tracer species in central Greenland ice cores have been used to determine the source of BC in snow over the past 215 years (McConnell et al., 2007). Chemical analyses combined with air mass back-trajectory modeling indicate that eastern North American boreal forest fires were the major source of BC in Greenland precipitation prior to industrialization $(\sim 1850)$. Since 1850, the BC deposited to Greenland snow appears to have originated primarily from industrial activities in North America (1850-1950) and Asia (1950-present). It is not known how representative these results are for other regions of the Arctic.

In years of intense burning, boreal forest fires can be an important source of BC throughout the Arctic. Stohl et al. (2006) found Pan-Arctic enhancements of aerosol light absorption during the summer of 2004, a year with strong burning in Canada and Alaska, and a coincident decrease in snow albedo at Summit, Greenland. Measurements of BC in snow at Summit confirm the deposition of BC to the snow surface. The summer of 2004 stands out as having the highest BC concentrations in snow in recent years (Hagler et al., 2007) yet the range of concentrations (1.0-1.4 $\left.\mathrm{ng} \mathrm{g}^{-1}\right)$ was far too low to significantly affect snow albedo if the $\mathrm{BC}$ were uniformly distributed in the upper snow layers (Warren and Wiscombe, 1985, Fig. 2). A thin layer of BC on the top surface might reduce albedo until it is covered with new snow. However, even if the snow albedo at Summit is usually unaffected by BC, this does not rule out a significant effect at lower-elevation locations in the Arctic, where average BC concentrations are usually much larger. Boreal forest fires in Siberia may have a larger impact than those in North America because of the larger burn area (Stohl, 2006). The fires occurring in Siberia in 2003 have been estimated to account for 16 to $33 \%$ of the observed aerosol optical thickness and 40 to $56 \%$ of the mass of $\mathrm{BC}$ deposited north of $75^{\circ} \mathrm{N}$ in spring and summer (Generoso et al., 2007).

Climate forcings also result from aerosol-cloud interactions. The aerosol first indirect effect in the shortwave occurs when pollution particles lead to an increase in cloud droplet number concentration, a decrease in the size of the droplets, and a corresponding increase in shortwave cloud albedo (Twomey, 1977). Measurements made at Barrow, Alaska, over a four year period indicate that episodic Arctic Haze events produce high cloud drop number concentrations and small cloud drop effective radii in low-level cloud 

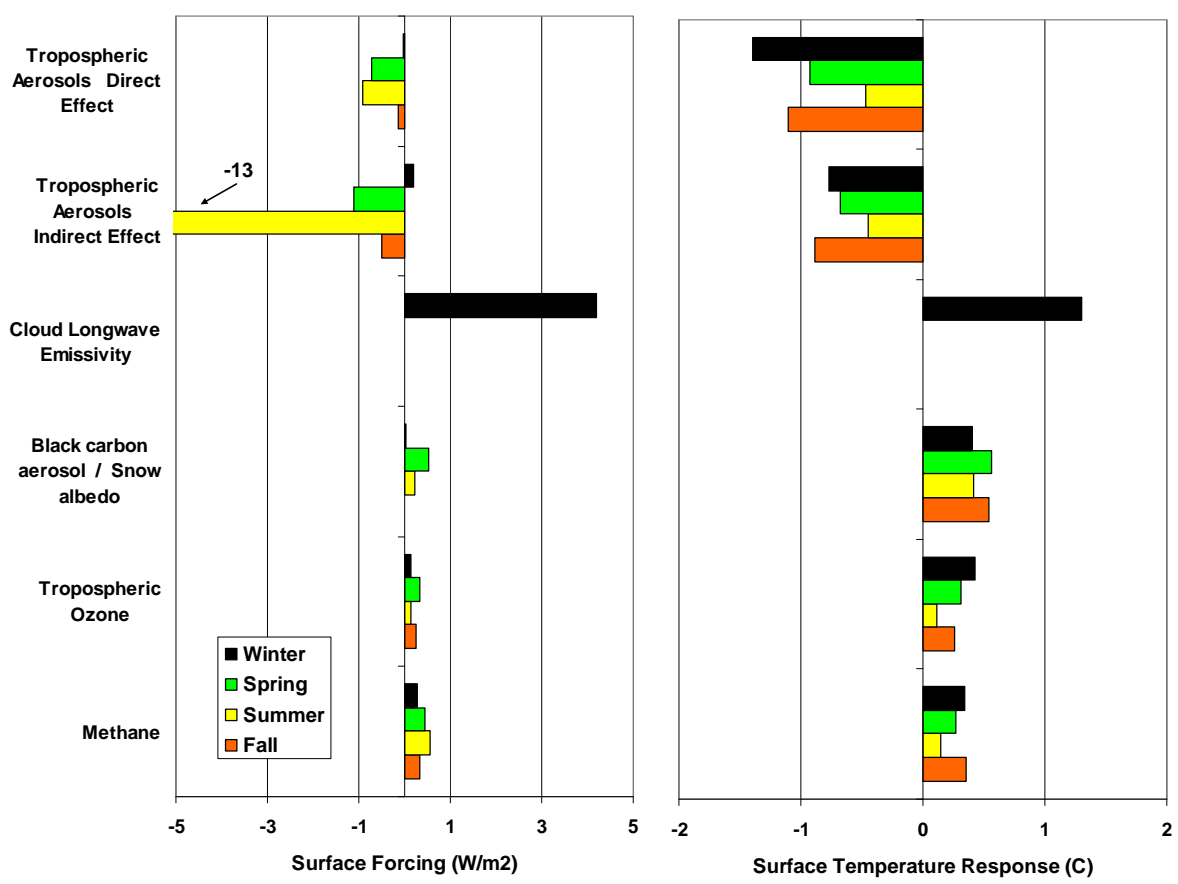

Fig. 2. Seasonally averaged values of radiative forcing and temperature response at the surface $\left(F_{S}\right.$ and $\Delta T_{S}$, respectively) for $60^{\circ}$ to $90^{\circ} \mathrm{N}$ based on the calculations described in Sect. 2 and Table 1. Values for Cloud Longwave Emissivity are not seasonal averages as they only include times when pollution aerosol and clouds were coincident. Central values of $F_{S}$ and $\Delta T_{S}$ are plotted in cases where a range of values was reported in Table 1.

microstructures (Garrett et al., 2004). Similar aerosol-cloud interactions can also lead to a significant longwave forcing. When the cloud drop number concentration of thin Arctic liquid-phase clouds is increased through interaction with anthropogenic aerosols, the clouds become more efficient at trapping and re-emitting longwave radiation (Garrett and Zhao, 2006; Lubin and Vogelmann, 2006). Over dark oceans when the sun is high, the shortwave indirect effect is expected to cool the surface but for a low sun over bright Arctic surfaces, the longwave effect is expected to dominate. Lubin and Vogelmann (2007) performed radiative transfer simulations to assess the relative magnitudes of shortwave and longwave downwelling fluxes due to Arctic haze aerosols. During March and April, shortwave downwelling fluxes were found to be comparable in magnitude to longwave fluxes. During May and June, however, the shortwave fluxes exceeded those in the longwave.

Aerosol-cloud interactions may also increase cloud cover by increasing cloud droplet number concentrations. The result is a decrease in cloud drop size, a decrease in precipitation, and an increase in cloud lifetime (Albrecht, 1989). Finally, increasing cloud drop number concentrations may be associated with a reduced rate of ice formation in mixedphase Arctic clouds which reduces cloud desiccation by ice and increases cloud longwave emissivity (Girard et al., 2005). However, ice formation mechanisms in common mixed-phase clouds remain very poorly understood (Fridlind et al., 2007).

\subsection{Summary of the forcing due to short-lived pollutants}

The magnitude of the forcing by each short-lived pollutant depends on the seasonality of a number of inter-related factors including radiation, precipitation, surface albedo, snow and ice coverage, and pollutant transport. In Table 1 estimates are presented of seasonally averaged forcing and the surface temperature response for the short-lived pollutants. Details of the calculations are given in Sect. 3. Although average estimates of temperature response may not be the most informative measure of the impact of short-lived pollutants, they serve as a starting point and can indicate directions for future research and mitigation strategies.

\section{Methods}

Radiative forcings and temperature response values for methane, tropospheric ozone, and tropospheric aerosols are presented so that the impact of these individual forcing agents can be compared in terms of seasonality, forcing at the surface $\left(F_{S}\right)$, forcing at the top of atmosphere $\left(F_{\mathrm{TOA}}\right)$, and surface temperature response $\left(\Delta T_{S}\right)$. 
Table 1. Comparison of the seasonality and magnitude of the forcing as well as the surface temperature response due to short-lived pollutants in the Arctic $\left(60^{\circ}\right.$ to $\left.90^{\circ} \mathrm{N}\right)$. Values of $F_{S}$ and $F_{\mathrm{TOA}}$ are reported here as the change in the instantaneous forcing due to the addition of fossil fuel and biofuel emissions to present-day biomass burning emissions. Winter $=$ DJF, Spring $=$ MAM, Summer $=$ JJA, Fall $=$ SON.

\begin{tabular}{|c|c|c|c|c|c|}
\hline Forcing Agent & Season & $F_{S}\left(\mathrm{~W} \mathrm{~m}^{-2}\right)$ & $F_{\mathrm{TOA}}\left(\mathrm{W} \mathrm{m}^{-2}\right)$ & $\begin{array}{l}F_{\mathrm{TOA}^{-}} F_{S} \\
\left(\mathrm{~W} \mathrm{~m}^{-2}\right)\end{array}$ & $\Delta T_{S}{ }^{\mathrm{a}}\left({ }^{\circ} \mathrm{C}\right)$ \\
\hline \multicolumn{6}{|c|}{ Tropospheric Aerosols - Direct Effect ${ }^{b}$} \\
\hline $\begin{array}{l}\text { Total* Fossil + Bio Fuel } \\
\text { (Biomass Burning) } \\
{ }^{*} \mathrm{SO}_{4}^{=}+\mathrm{OC}+\mathrm{BC}\end{array}$ & $\begin{array}{l}\text { Winter } \\
\text { Spring } \\
\text { Summer } \\
\text { Fall }\end{array}$ & $\begin{array}{l}-0.04(-0.001) \\
-0.72(-0.1) \\
-0.93(-0.43) \\
-0.14(-0.07)\end{array}$ & $\begin{array}{l}0.08(0.004) \\
0.92(0.17) \\
0.11(0.16) \\
0.08(0.04)\end{array}$ & $\begin{array}{l}0.12(0.005) \\
1.6(0.27) \\
1.0(0.59) \\
0.22(0.11)\end{array}$ & $\begin{array}{l}-1.4^{\mathrm{c}} \\
-0.93^{\mathrm{c}} \\
-0.47^{\mathrm{c}} \\
-1.1^{\mathrm{c}}\end{array}$ \\
\hline $\mathrm{SO}_{4}^{=}$Fossil Fuel & $\begin{array}{l}\text { Winter } \\
\text { Spring } \\
\text { Summer } \\
\text { Fall }\end{array}$ & $\begin{array}{l}-0.006 \\
-0.26 \\
-0.50 \\
-0.07\end{array}$ & $\begin{array}{l}-0.01 \\
-0.32 \\
-0.54 \\
-0.08\end{array}$ & $\begin{array}{l}-0.006 \\
-0.06 \\
-0.04 \\
-0.01\end{array}$ & \\
\hline $\begin{array}{l}\text { OC Fossil+Bio Fuel } \\
\text { (Biomass burning) }\end{array}$ & $\begin{array}{l}\text { Winter } \\
\text { Spring } \\
\text { Summer } \\
\text { Fall }\end{array}$ & $\begin{array}{l}-0.003(0) \\
-0.06(-0.05) \\
-0.04(-0.24) \\
-0.008(-0.04)\end{array}$ & $\begin{array}{l}0(0) \\
0.03(0.02) \\
-0.01(-0.09) \\
-0.001(-0.02)\end{array}$ & $\begin{array}{l}0.003(0) \\
0.09(0.07) \\
0.03(0.15) \\
0.007(0.02)\end{array}$ & \\
\hline $\begin{array}{l}\text { BC Fossil + Bio Fuel } \\
\text { (Biomass burning) }\end{array}$ & $\begin{array}{l}\text { Winter } \\
\text { Spring } \\
\text { Summer } \\
\text { Fall }\end{array}$ & $\begin{array}{l}-0.03(-0.001) \\
-0.39(-0.05) \\
-0.39(-0.19) \\
-0.07(-0.03)\end{array}$ & $\begin{array}{l}0.09(0.004) \\
1.2(0.15) \\
0.66(0.25) \\
0.16(0.05)\end{array}$ & $\begin{array}{l}0.12(0.005) \\
1.6(0.20) \\
1.0(0.44) \\
0.23(0.08)\end{array}$ & \\
\hline \multicolumn{6}{|c|}{ Tropospheric Aerosols - Indirect Effects } \\
\hline $\begin{array}{l}\text { Total* Fossil + Bio Fuel Cloud albedo } \\
+ \text { cloud cover } \\
\mathrm{SW}, \mathrm{LW}, \mathrm{SW}+\mathrm{LW} \\
{ }^{*} \mathrm{SO}_{4}^{=}+\mathrm{OC}+\mathrm{BC}\end{array}$ & $\begin{array}{l}\text { Winter } \\
\text { Spring } \\
\text { Summer } \\
\text { Fall }\end{array}$ & $\begin{array}{l}-0.04,0.24,0.2^{\mathrm{d}} \\
-3.0,1.9,-1.1 \\
-12.2,-0.5,-13 \\
-0.4,-0.1,-0.5\end{array}$ & $\begin{array}{l}0.07,-0.1,-0.03^{\mathrm{e}} \\
0,0.1,0.1 \\
6.6,-0.5,6.1 \\
0.49,-0.9,-0.41\end{array}$ & $\begin{array}{l}0.11,-0.34,-0.23 \\
3.0,-1.8,1.2 \\
19,0,19 \\
0.89,-0.8,0.09\end{array}$ & $\begin{array}{l}-0.77^{\mathrm{f}} \\
-0.68^{\mathrm{f}} \\
-0.45^{\mathrm{f}} \\
-0.89^{\mathrm{f}}\end{array}$ \\
\hline Cloud longwave emissivity & Winter & +3.3 to $5.2^{\mathrm{g}}$ & & & 1 to $1.6^{\mathrm{g}}$ \\
\hline \multicolumn{6}{|c|}{ Black carbon aerosol - Snow Albedo } \\
\hline BC Fossil + Bio Fuel & $\begin{array}{l}\text { Winter } \\
\text { Spring } \\
\text { Summer } \\
\text { Fall }\end{array}$ & $\begin{array}{l}0.02^{\mathrm{h}} \\
0.53^{\mathrm{h}} \\
0.21^{\mathrm{h}} \\
0.002^{\mathrm{h}}\end{array}$ & 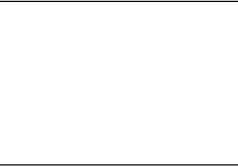 & & $\begin{array}{l}0.27-0.61^{\mathrm{h}} \\
0.36-0.76^{\mathrm{h}} \\
0.24-0.59^{\mathrm{h}} \\
0.31-0.76^{\mathrm{h}}\end{array}$ \\
\hline \multicolumn{6}{|c|}{ Tropospheric Ozone - GHG warming + SW absorption ${ }^{\mathrm{i}}$} \\
\hline $\begin{array}{l}\mathrm{O}_{3} \text { Fossil + Bio Fuel and } \\
\text { Biomass burning }\end{array}$ & $\begin{array}{l}\text { Winter } \\
\text { Spring } \\
\text { Summer } \\
\text { Fall }\end{array}$ & & $\begin{array}{l}0.13 \\
0.34 \\
0.14 \\
0.24\end{array}$ & & $\begin{array}{l}0.43 \\
0.31 \\
0.11 \\
0.26\end{array}$ \\
\hline \multicolumn{6}{|c|}{ Methane - GHG warming ${ }^{\mathrm{j}}$} \\
\hline Methane & $\begin{array}{l}\text { Winter } \\
\text { Spring } \\
\text { Summer } \\
\text { Fall }\end{array}$ & & $\begin{array}{l}0.29 \\
0.45 \\
0.55 \\
0.34\end{array}$ & & $\begin{array}{l}0.34 \\
0.27 \\
0.15 \\
0.35\end{array}$ \\
\hline
\end{tabular}


Table 1. Continued.
a Zonal mean temperature change at the surface for $60^{\circ}$ to $90^{\circ} \mathrm{N}$. Climate models used to calculate the Arctic response were forced globally (not just within the Arctic region) with changing composition.
${ }^{\mathrm{b}} F_{S}$ and $F_{\mathrm{TOA}}$ are based on the GISS ModelE GCM, using present-day fossil, bio-fuel, and biomass burning emissions rela- tive to present-day biomass burning emissions (Koch and Hansen, 2005). Values for present-day biomass burning emissions are shown in parentheses.
${ }^{c}$ Values are reported as the zonal mean temperature change for 1880 to 2003 at the surface relative to half present-day biomass burning emissions. Biofuel emissions are not included in these calculations. A small fossil fuel source was included for the late 1880s. Taken from Fig. 11 of Hansen et al. (2007).
${ }^{\mathrm{d}}$ Direct plus indirect effects (cloud albedo and cloud cover) together. Based on the GISS ModelE GCM, using present-day fossil, bio-fuel, and biomass burning emissions relative to present-day biomass burning emissions (Menon and Rotstayn, 2006). Three values are given: shortwave, longwave, and shortwave plus longwave forcing.
e Based on the GISS ModelE GCM, for changes in net cloud radiative forcing using the same emissions scenario as described above. Three values are given: shortwave, longwave, and shortwave plus longwave forcing.
${ }^{\mathrm{f}}$ Temperature change due to cloud cover aerosol indirect effect only. Taken from Fig. 11 of Hansen et al. (2007).
$\mathrm{g}$ Based on measurements of the sensitivity of low-level cloud emissivity to pollution at Barrow, Alaska (Garrett and Zhao, 2006). Not a seasonal average as it only includes times when pollution aerosol and clouds were coincident.
$\mathrm{h}$ Based on radiative transfer calculations with SNICAR coupled to the NCAR CAM3 using present-day fossil, bio-fuel, and biomass burning emissions relative to present-day biomass burning emissions (Flanner et al., 2007).
i Ozone forcing calculated at the tropopause over 60-90 $\mathrm{N}$ for 1900-2000 (Shindell et al., 2006).
j Methane's forcing and response are estimated based on simulations for 1900-2001 driven by changes in all well-mixed greenhouse gases (WMGHGs), accounting for the fractional contribution of methane to the total forcing (0.20) and its efficacy relative to the total WMGHG efficacy (1.05/1.02). As the well-mixed greenhouse gases are evenly distributed, we believe this is a realistic approach. Values are calculated at the tropopause. Methane's role in ozone production is included in the tropospheric ozone calculation. Based on the contribution to the global increase in tropospheric ozone, it is responsible for $\sim 50 \%$ of the overall tropospheric ozone increase. Its percentage contribution to the Arctic ozone concentration will be lower, however, as ozone changes in the Arctic are dominated by increases in $\mathrm{NO}_{\mathrm{x}}$ (Shindell et al., 2005).

\subsection{Surface and top of atmosphere forcing}

Seasonally averaged values of $F_{S}, F_{\mathrm{TOA}}$, and $F_{\mathrm{TOA}}-F_{S}$ are shown in Table 1 for the short-lived forcing agents discussed in Sect. 2. In addition, seasonally averaged values of $F_{S}$ and $\Delta T_{S}$ are shown in Fig. 2 for each of the forcing mechanisms included in the table. Values of $F_{S}$ and $F_{\mathrm{TOA}}$ due to direct radiative forcing by tropospheric aerosols are based on GISS ModelE GCM calculations (Koch and Hansen, 2005). They are reported as the change in instantaneous forcing due to adding present-day fossil fuel plus biofuel emissions to the baseline simulation where the baseline simulation used present-day biomass burning emissions. For comparison, values also are shown for the forcing contributed by present-day biomass burning emissions based on GISS ModelE GCM calculations. $F_{S}$ and $F_{\mathrm{TOA}}$ were calculated for the "total" aerosol which includes sulfate, organic carbon (OC), and black carbon (BC) and for the individual aerosol species (sulfate, OC, and BC). Forcings derived from these globalscale calculations were averaged over $60^{\circ}$ to $90^{\circ} \mathrm{N}$.

Values of $F_{S}$ and $F_{T O A}$ due to indirect radiative forcing by tropospheric aerosols are based on GISS ModelE GCM calculations for direct plus indirect effects where the indirect effects include those of cloud albedo and cloud cover (e.g., Menon and Rotstayn, 2006). Shortwave, longwave, and shortwave plus longwave values of $F_{S}$ and $F_{\mathrm{TOA}}$ are given for the "total" aerosol (sulfate, $\mathrm{OC}$, and $\mathrm{BC}$ ). As for the direct radiative forcing calculations, forcings are reported as the change in instantaneous forcing due to adding fossil fuel plus biofuel emissions to the baseline simulation where the baseline simulation used present-day biomass burning emissions.

Increased cloud longwave emissivity due to pollution haze is assigned a wintertime range of values of $F_{S}$ based on the analysis of Garrett and Zhao (2006). Using four years of ground-based aerosol and radiation measurements, Garrett and Zhao (2006) found that where thin water clouds and pollution are coincident, there is an increase in cloud longwave emissivity resulting from haze layers at altitudes above the surface. Rather than seasonal averages, the range of observed sensitivity and corresponding surface temperature response are reported here.

Forcing by BC in snow due to present-day fossil, biofuel, and biomass burning emissions for the Arctic $\left(60^{\circ}\right.$ to $90^{\circ} \mathrm{N}$ ) was calculated relative to present-day biomass burning emissions using SNICAR (Snow, Ice, and Aerosol Radiative model) coupled to the NCAR CAM3 general circulation model (Flanner et al., 2007).

$F_{\mathrm{TOA}}$ for tropospheric ozone as reported in Table 1 is the instantaneous forcing at the tropopause based on GISS model II/ chemistry calculations for the 1880 to 2003 time period (Shindell et al., 2006). $F_{\mathrm{TOA}}$ for methane is calculated at 
the tropopause from simulations for 1900 to 2001 driven by changes in all well-mixed greenhouse gases (WMGHGs) accounting for the fractional contribution of methane to the total forcing (0.20) and its efficacy relative to the total WMGHG efficacy (1.05/1.02). The role of methane in ozone production is included in the tropospheric ozone calculation.

\subsection{Surface temperature response}

Seasonally averaged values of the surface temperature response due to forcing by the short-lived pollutants are shown in Table 1. The climate models used to calculate the Arctic response were forced globally with changing atmospheric composition. Values for tropospheric aerosol direct and indirect effects are based on GISS Model E climate simulations (Hansen et al., 2007, Fig. 11). Indirect effects only include the temperature response due to changes in cloud cover. Values are reported as the zonal mean temperature change for 1880 to 2003 , where the 1880 simulation includes a small fossil fuel source and biomass burning emissions at half of present-day levels. Biofuel emissions are not included in these calculations. The temperature response due to deposition of BC on snow and ice surfaces was calculated with the SNICAR (Snow, Ice, and Aerosol Radiative model) coupled to the NCAR CAM3 general circulation model using the same emissions scenario as described in the previous section (Flanner et al., 2007).

The temperature response due to forcing by tropospheric ozone and methane are based on GISS Model E calculations detailed in Shindell et al. (2006) and Hansen et al. (2007) using the regional averages and time periods described above. The surface temperature response resulting from increased cloud longwave emissivity is based directly on values of $F_{S}$ reported in Table 1 (Garrett and Zhao, 2006).

\subsection{Model performance and uncertainties}

As these are the first Arctic estimates of seasonally averaged forcing for the short-lived pollutants, it is difficult to assess model performance by comparing to values calculated using other models. It is possible, however, to compare geographical distributions of aerosol species and forcing estimates averaged over annual and global scales. The NASA GISS model used in the calculation of the aerosol direct and indirect forcings was thoroughly compared to other global aerosol models as part of the AeroCom initiative. A comparison of black carbon mass in the polar regions that included sixteen models found that two models had greater than $7 \%$ of their BC mass in the Arctic, 5 had 6 to $7 \%$ of their BC in the Arctic, and nine had less than $6 \%$ of their $\mathrm{BC}$ in the Arctic (Textor et al., 2006). Falling within this range of variability, the GISS model had 7\% of the BC in the Arctic. Hence, the GISS model was at the higher end of the range but was not an outlier.
Also as a part of the AeroCom initiative, Schulz et al. (2006) compared annually averaged total aerosol direct forcing from nine global aerosol models. The GISS model and one other (UIO_GCM) had the most positive values of aerosol direct forcing within the Arctic $\left(0.02\right.$ to $0.05 \mathrm{~W} \mathrm{~m}^{-2}$ vs. 0.0 to $0.2 \mathrm{~W} \mathrm{~m}^{-2}$ ) due to a larger load of $\mathrm{BC}$ transported to the region. However, a comparison of modeled BC concentrations from the GISS model to those measured at Spitsbergen and two Alaskan sites did not reveal systematic biases within the GISS model (Koch et al., 2007). The ratio of modeled to observed concentrations was found to be between 0.5 and 0.67 at Spitsbergen (i.e., model values were lower than observed) and between 0.67 to 1.5 at the two sites in Alaska.

Uncertainties in model calculations of the BC-snow forcing arise from emissions, effects of snow aging and meltwater scavenging, black carbon optical properties, and snow cover fraction with the contribution to uncertainty following the order listed. Based on uncertainties in these five factors, the potential range in black carbon-snow forcing is $-87 \%$ to $+240 \%$ relative to the central estimates given here. This large range is indicative of the current state of understanding of this forcing mechanism. On a global, annually averaged basis, the model used in this study produced a forcing estimate for fossil fuel and bio-fuel black carbon of $+0.04 \mathrm{~W} \mathrm{~m}^{-2}$ which is slightly smaller than those reported by Hansen et al. (2005) $\left(+0.05 \mathrm{~W} \mathrm{~m}^{-2}\right)$ and Jacobson (2004) $\left(+0.06 \mathrm{~W} \mathrm{~m}^{-2}\right)$.

Global, annual average radiative forcing due to tropospheric ozone increases from the preindustrial to the present have been calculated in a number of models, though observational evidence to constrain these calculations is minimal. The time-evolving tropospheric ozone used in the GISS climate simulations discussed here was taken from Shindell et al. (2003). The adjusted global annual average radiative forcing due to preindustrial to present-day tropospheric ozone change in that study, $0.30-0.33 \mathrm{~W} \mathrm{~m}^{-2}$ depending on emissions, is near the center of the $0.25-0.45 \mathrm{~W} \mathrm{~m}^{-2}$ range (with a mean of $0.34 \mathrm{~W} \mathrm{~m}^{-2}$ and a standard deviation of $0.07 \mathrm{~W} \mathrm{~m}^{-2}$ ) seen in the most recent IPCC assessment (IPCC, 2007). Additional uncertainties in the forcing due to tropospheric ozone come from lack of knowledge about preindustrial emissions of ozone precursors. Uncertainty in the global mean annual average radiative forcing due to methane increases from the preindustrial to the present is very small, at only $10 \%$ of the total forcing of $0.48 \mathrm{~W} \mathrm{~m}^{-2}$ (IPCC, 2007).

The sensitivity of the Arctic to either local or remote forcing has not been quantified across a number of models. Therefore, it is not possible to compare the responses reported here with other studies. It is possible to consider climate sensitivities, however, where the climate sensitivity is defined as the change in equilibrium global surface-air temperature due to a doubling of carbon dioxide. Climate sensitivity of the GISS and NCAR models used here are both $2.7^{\circ} \mathrm{C}$ which is in the middle of the range seen in current 
state-of-the-art global climate models $\left(2\right.$ to $\left.4.5^{\circ} \mathrm{C}\right)$ (Kiehl et al., 2006; Kiehl, 2007).

\section{Seasonality and magnitude of forcing due to short- lived pollutants and surface temperature response}

Forcing due to tropospheric ozone is at a maximum during spring (Table 1) when transport of ozone is efficient, radiation is abundant, and substantial ozone precursors persist from the winter buildup that occurs under conditions of low photochemical loss. Summertime forcing could also be significant, particularly when agricultural or boreal forest fire emissions increase ozone levels in the Arctic. The values shown in Table 1 for summertime are based on a standard climatology for present day biomass burning emissions (including forest fires) (Shindell et al., 2006). As such, they do not capture years with exceptionally large boreal fires. Methane forcing, which is not limited by the seasonality of pollutant transport, is at a maximum during spring and summer due to warmer surface temperatures and, hence, a more powerful greenhouse effect. The surface response for both ozone and methane, indicated here as an increase in surface temperature of $0.43^{\circ}$ and $0.34^{\circ} \mathrm{C}$, respectively (Table 1), is high in winter when the forcing is at a minimum. This offset implies that the Arctic surface temperature exhibits a delayed response to forcing (either local or extrapolar), is dynamically driven by forcings in other regions of the globe during this season, or is enhanced by erosion of the surface-based temperature inversion which is most prominent in winter.

In the Arctic, the magnitude and mechanism of climate forcing due to aerosols is controlled by an interplay among the seasonal timing of transport, available radiation, snow/ice melt, and deposition. In winter and early spring, when transport of pollutants from the mid-latitudes is most efficient, solar radiation is limited so that the radiation balance is driven primarily by thermal fluxes. Interactions between the pollutant aerosol haze and the thin water clouds present at that time of year lead to an increase in longwave emissivity of thin clouds. Long-term ground based observations indicate that, when pollution and clouds are coincident, the result is a positive forcing at the surface of +3.3 to $5.2 \mathrm{~W} \mathrm{~m}^{-2}$ which is estimated to yield an enhanced surface warming of $1^{\circ}$ to $1.6^{\circ} \mathrm{C}$ (Garrett and Zhao, 2006).

Concentrations of BC are enhanced in the Arctic atmosphere during winter and spring due to the transport of Arctic Haze from the mid-latitudes. The deposition of the soot onto the highly reflective snow/ice surfaces lowers the surface albedo and yields a positive surface forcing of $0.53 \mathrm{~W} \mathrm{~m}^{-2}$ in the spring, the season of maximum forcing (Flanner et al., 2007). The corresponding increase in surface temperature is about $0.5^{\circ} \mathrm{C}$.

Finally, direct shortwave climate forcing by atmospheric aerosols occurs when solar radiation is abundant and springtime Arctic Haze or summertime fire plumes are present leading to a reduction in the amount of solar radiation reaching the surface. The result is a negative surface forcing during the spring $\left(-0.72 \mathrm{~W} \mathrm{~m}^{-2}\right.$ for the total fossil + bio-fuel + biomass burning aerosol) and a change in surface temperature of $-0.93^{\circ} \mathrm{C}$. As $F_{S}$ is an instantaneous forcing, this temperature change applies before the surface equilibrates with the warmer atmosphere. Additional effects include a reduction in Arctic sea level pressure and an increase in snow/ice cover. These aerosol impacts on circulation and the cryosphere may contribute to an offset between the season of maximum forcing (spring and summer) and maximum temperature response (winter).

Mentioned in the discussion above but worth reiterating here is the offset between forcing and surface temperature response in several of the climate model simulations included in Table 1. Recently reported modeling results indicate that during the boreal summer, Arctic temperature response is well-correlated with either global or Arctic forcing (Shindell, 2007). During the remaining seasons, however, the surface temperature response follows the global or Northern Hemisphere extratropical forcing more closely than local Arctic forcing, indicating that distant regions have a large impact on Arctic climate.

Conditions specific to the Arctic must also be considered when comparing the seasonality of forcing and the surface temperature response. For example, during the summer, the tropospheric aerosol indirect effect has the largest value of $F_{S}$ but the smallest value of $\Delta T_{S}$. This discrepancy occurs because surface temperatures over the Arctic Ocean are limited as long as sea ice is present. This scenario (discrepancy between seasonal maxima in forcing and response) is likely to change with future decreases in sea ice extent.

\section{Arctic climate mitigation opportunities as understood today}

Reducing emissions of $\mathrm{CO}_{2}$ globally will reduce the rate of surface warming and snow/ice melt in the Arctic. However, targeting emissions of short-lived pollutants along with $\mathrm{CO}_{2}$ has the advantage of impacting Arctic climate on a more immediate timescale. The most effective mitigation strategy will target those pollutants that dominate surface radiative absorption. Specific mitigation opportunities include the following.

Methane. Reducing methane emissions will require targeting major controllable anthropogenic sources. Because of the relatively long lifetime of methane, reductions that benefit the Arctic can occur globally. The U.S. EPA has examined major methane sources and identified the following areas where considerable mitigation potential exists. These include worldwide coal mine desgasification and mine ventilation air capture, identification and repair of natural gas leaks, and better handling of municipal solid wastes including using landfill methane as a source of energy. On a global 
basis, coal mine methane accounts for $8 \%$ of total methane emissions due to anthropogenic activities (US EPA, 2006). Methane is removed from active mines with large ventilation systems and from both active and abandoned mines with degasification or gas drainage systems. Coal mine methane can be captured and used for power production, heating, and in manufacturing and industrial applications.

Ozone and black carbon - targeting source regions. Ozone and black carbon are not globally well mixed due to their relatively short lifetimes. Hence, specific source regions must be targeted to lessen their impacts in the Arctic. On timescales of days to weeks, northern Eurasia is the strongest source region for Arctic air pollution, especially in the lower troposphere (Barrie, 1986; Klonecki et al., 2003; Stohl, 2006). Therefore, to decrease concentrations of ozone precursors and black carbon in the lower atmosphere, emissions in this region should be reduced. The source regions of short-lived pollutants in the upper Arctic atmosphere include northern Eurasia and also areas in North America and Asia (Klonecki et al., 2003; Koch and Hansen, 2005; Stohl, 2006). Therefore, a substantial reduction of ozone and BC in the upper troposphere will require more widespread emission reductions throughout the Northern Hemisphere. The correspondence between surface temperature response in the Arctic and global and Northern Hemisphere extratropical forcings due to ozone emphasizes the need to reduce ozone on a northern hemisphere and global basis to reduce climate response in the Arctic. Finally, emissions of ozone precursors and $\mathrm{BC}$ within the Arctic should be kept at a minimum as these will have a disproportionately large impact on withinArctic concentrations.

Ozone and black carbon - targeting sources. Reducing methane emissions as outlined above will decrease ozone production. Reductions in $\mathrm{NO}_{\mathrm{x}}$ also will contribute but, at the same time, will decrease $\mathrm{OH}$ which is the major sink for methane. Hence, an ozone reduction strategy using $\mathrm{NO}_{\mathrm{x}}$ controls that benefits climate will also include methane, NMVOCs, and/or carbon monoxide reductions. Carbon monoxide forms when carbon in fuel does not burn completely. The main source of carbon monoxide is gasolinepowered vehicles. Abatement options include catalysts, routine inspection and maintenance, and addition of oxygencontaining compounds to gasoline (US EPA, 1993). The majority of anthropogenic NMVOCs released into the atmosphere are from transportation sources and industrial processes utilizing solvents such as surface coating (paints), printing (inks), and petrochemical processing. The choice of NMVOC control measure is compound specific. Options include installation of control devices such as an incinerator, a solvent recovery system, limits on the amount of solvent used in products, and product stabilization (US EPA, 1999). In addition to targeting transportation and industrial sources, reducing or eliminating agricultural fires in eastern Europe and northern Asia would effectively reduce CO, NMVOC, and ozone concentrations in the Arctic.
Reducing black carbon concentrations will require targeting sources that emit aerosols with a high absorptivity and relatively low reflectance (e.g., diesel combustion and residential stoves). Reducing within-Arctic emissions of black carbon (e.g., generators) and implementing emission controls on marine vessels operating within Arctic waters (particularly in light of the likely increase in shipping activity as the snow/ice pack decreases) will also be required. Additional strategies include reducing prescribed agricultural burns in eastern Europe so that black carbon emission and deposition does not occur in spring as radiation is increasing and the area of snow/ice pack is large. Reducing ozone and black carbon emissions has the added benefit of improving air quality and decreasing associated health hazards.

\section{Future directions for research}

Many of the impacts of short-lived pollutants on Arctic climate are not well understood or quantified. This lack of understanding is evident in the large range of potential forcing values calculated by single and multiple models as discussed in Sect. 3. This paper presents the first seasonally averaged forcing and temperature response estimates focused solely on the Arctic for a broad range of chemical species. Being a first attempt, there is much work left to be done to more accurately quantify the impacts of each pollutant and to identify the most effective mitigation strategies. Specific scientific issues and areas of uncertainty in need of future research are discussed below.

Methane. Wetland and permafrost methane emissions within the Arctic and sub-Arctic that result from rising surface temperatures are highly uncertain. Quantifying these emissions and how they might be expected to change in the coming years in response to rising temperatures is critical to understanding the impact of methane on Arctic climate.

Ozone. The effectiveness of controlling near-Arctic or within-Arctic $\mathrm{NO}_{\mathrm{x}}$ emissions to reduce tropospheric ozone within the Arctic is unknown. Local $\mathrm{NO}_{\mathrm{x}}$ emissions are likely to become significant if Arctic shipping activity increases as predicted. Research is needed to improve our understanding of reactive nitrogen chemistry and the oxidation capacity of the Arctic atmosphere.

Black carbon. Our understanding of deposition of black carbon-containing aerosol and trends in atmospheric concentrations of black carbon is constrained by limited measurements. Questions concerning responsible source regions, transport, and atmospheric processing of the aerosol persist. Simultaneous pan-Arctic measurements of atmospheric and deposited BC combined with modeling studies are needed to identify sources, particularly those that impact the timing and rate of snow/ice melt, and to gain a better understanding of transport pathways and deposition processes. Recent measurements of BC and tracer species in a Greenland ice core demonstrated the power of this method for identifying 
source regions of $\mathrm{BC}$ at one site in the Arctic over the last 200 years (McConnell et al., 2007). Similar measurements at other Arctic sites would help to identify differences in source regions of $\mathrm{BC}$ across the Arctic. This information can be used to assess the emission inventories used in global aerosol models. A comparison of 16 global aerosol models revealed that harmonizing aerosol sources has only a small impact on differences in calculated global aerosol burdens (Textor et al., 2007). Rather, the amount of BC estimated to be in the Arctic is dependent on model-specific treatment of vertical mixing, meridional transport, and aerosol removal (Textor et al., 2006, 2007). Measurements of atmospheric $\mathrm{BC}$ (or aerosol light absorption) are required across the Arctic and in the vertical to assess modeled transport and aerosol removal processes. Satellite observations of aerosol vertical and horizontal distributions also will help in model validation.

Other tropospheric aerosols - surface warming. The enhancement of longwave emissivity from thin liquid-phase Arctic clouds due to interactions with anthropogenic aerosols may lead to significant surface temperature increases. These increases occur in phase with sea ice melt, potentially leading to a resonant amplification. As for black carbon, combined measurement and modeling studies are required to determine the source regions, chemical composition, and climate impact of different aerosol types. Measurements at sites with radiation instrumentation are particularly key so that information about aerosol and cloud properties, the impact of aerosols on cloud properties, and the resulting impacts on the radiation budget can be assessed. In addition, further research is required to evaluate the role of aerosols in ice formation in low level mixed-phase clouds.

Other tropospheric aerosols - surface cooling. Reflective aerosols in atmospheric layers prevent incoming solar radiation from reaching the ground and yield a cooling at the surface. Hence, reductions in aerosol concentrations within the Arctic and in distant source regions may contribute to Arctic warming (Shindell, 2007). Assessing the overall impact of tropospheric aerosols in the Arctic (direct and indirect effects) is required to determine how reductions in aerosol concentrations will affect Arctic climate.

Feedbacks and Climate Responses. The feedback mechanisms that come into play due to the combination of forcings from all pollutants and the complexity of the Arctic environment are highly uncertain. Models are the only tool available to assess the climate response of individual and combined forcings and feedback mechanisms. In addition, models are required for predictions of climate impacts of the short-lived pollutants over the coming decades. The measurements described above will serve to constrain models thereby improving our predictive capability and our understanding of climate sensitivites to forcings. Modeling efforts required for a better understanding of feedbacks and climate responses include improved parameterizations of snow albedo and interactions between aerosol and mixed-phase clouds, studies that allow for the discrimination between forcings and feedbacks within the climate system, and multi-model comparisons aimed directly at emissions, transport, and atmospheric processes that impact the Arctic.

Mitigation. Modeling studies are required to determine the effectiveness of individual mitigation strategies on Arctic climate and, in particular, the surface temperature response. The choice of mitigation strategies is complicated as each pollutant source includes multiple chemical species (e.g., forest fires emit black carbon, organic carbon, and ozone). Accurate estimates of the climate impacts due to a specific mitigation strategy must take into account the simultaneous reduction of all species from a given source.

Acknowledgements. In January and November of 2007, workshops on the impacts of short-lived pollutants on Arctic climate were convened with sponsorship by NASA, CATF, NILU, IGAC and CPC. This article is a result of discussions at those workshops. This work was supported by the NOAA Climate Program Office. This is PMEL contribution number 3079.

Edited by: K. Carslaw

\section{References}

Albrecht, B. A.: Aerosols, cloud microphysics, and fractional cloudiness, Science, 245, 1227-1230, 1989.

Barrie, L. A.: Arctic air pollution-An overview of current knowledge, Atmos. Environ., 20, 643-663, 1986.

Cao, M., Gregson, K., and Marshall, S.: Global methane emissions and its sensitivity to climate change, Atmos. Environ., 32, 3293 3299, 1998.

Chameides, W. L., Fehsenfeld, F., Rodgers, M. O., et al.: Ozone precursor relationships in the ambient atmosphere, J. Geophys. Res., 97, 6037-6055, 1992.

Chapin, F. S., Sturm, M., Serreze, M. C., et al.: Role of landsurface changes in Arctic summer warming, Science, 310, 657660, 2005.

Christensen, T. R., Johansson, T., Akerman, J., et al.: Thawing subarctic permafrost : Effects on vegetation and methane emissions, Geophys. Res. Lett., 31, L04501, doi:10.1029/2003GL018680, 2004.

Clarke, A. D. and Noone, K. J.: Soot in the Arctic snowpack: a cause for perturbations in radiative transfer, Atmos. Environ., 19, 2045-2053, 1985.

Crutzen, P.: A discussion of the chemistry of some minor constituents in the stratosphere and troposphere, Pure Appl. Geophys., 106-108, 1385-1399, 1973.

Dentener, F., Stevenson, D., Cofala, J., Mechler, R., Amann, M., Bergamaschi, P., Raes, F., and Derwent, R.: The impact of air pollutant and methane emission controls on tropospheric ozone and radiative forcing: CTM calculations for the period 19902030, Atmos. Chem. Phys., 5, 1731-1755, 2005, http://www.atmos-chem-phys.net/5/1731/2005/.

Dlugokencky, E. J., Houweling, S., Bruhwiler, L., Masarie, K. A., Lang, P. M., Miller, J. B., and Tans, P. P.: Atmospheric methane levels off: Temporary pause or new steady-state?, Geophys. Res. Lett., 30(19), 1992, doi:10.1029/2003GL018126, 2003. 
Fiore, A. M., Jacob, D. J., Field, B. D., Streets, D. G., Fernandes, S. D., and Jang, C.: Linking ozone pollution and climate change: The case for controlling methane, Geophys. Res. Lett., 29(19), 1919, doi:10.1029/2002GL015601, 2002.

Flanner, M. G., Zender, C. S., Randerson, J. T., and Rasch, P. J.: Present-day climate forcing and response from black carbon in snow, J. Geophys. Res., 112, D11202, doi:10.1029/2006JD008003, 2007.

Fridlind, A. M., Ackerman, A. S., McFarquhar, G., Zhang, G., Poellot, M. R., DeMott, P. J., Prenni, A. J., and Heymsfield, A. J.: Ice properties of single-layer stratocumulus during the Mixed-Phase Arctic Cloud Experiment (M-PACE): Part II, Model results, J. Geophys. Res., 112, D24202, doi:10.1029/2007JD008646, 2007.

Garrett, T. J., Zhao, C., Dong, X., Mace, G. G., and Hobbs, P. V.: Effects of varying aerosol regimes on low-level Arctic stratus, Geophys. Res. Lett., 31, L17105, doi:10.1029/2004GL019928, 2004.

Garrett, T. J. and Zhao, C.: Increased Arctic cloud longwave emissivity associated with pollution from mid-latitudes, Nature, 440, 787-789, 2006.

Generoso, S., Bey, I., Attie, J.-L., and Breon, F.-M.: A satelliteand model-based assessment of the 2003 Russian fires: Impact on the Arctic region, J. Geophys. Res., 112, D15302, doi:10.1029/2006JD008344, 2007.

Girard, E., Blanchet, J. P., and Dubois, Y.: Effects of Arctic sulfuric acid aerosols on wintertime low-level atmospheric ice crystals, humidity and temperature at Alert, Nunavut, Atmos. Res., 73, 131-148, 2005.

Granier, C., Niemeier, U., Jungclaus, J. H., Emmons, L., Hess, P. G., Lamarque, J.-F., Walters, S., and Brasseur, G. P.: Ozone pollution from future ship traffic in the Arctic northern passages, Geophys. Res. Lett., 33, L13807, doi:10.1029/2006GL026180, 2006.

Hagler, G. S. W., Bergin, M. H., Smith, E. A., Dibb, J. E., Anderson, C., and Steig, E. J: Particulate and water-soluble carbon measured in recent snow at Summit, Greenland, Geophys. Res. Lett., 34, L16505, doi:10.1029/2007GL030110, 2007.

Haagen-Smit, A. J.: Chemistry and physiology of Los Angeles smog, Ind. Eng. Chem., 44, 1342-1346, 1952.

Hall, A. and X. Qu, Using the current seasonal cycle to constrain snow albedo feeback in future climate change, Geophys. Res. Lett., 33, L03502, doi:10.1029/2005GL025127, 2006.

Hansen, J. and Nazarenko, L.: Soot climate forcing via snow and ice albedos, Proc. Natl. Acad. Sci., 101, 423-428, 2004.

Hansen, J., Sato, M., Ruedy, R., et al.: Efficacy of climate forcings, J. Geophys. Res., 110, D18104, doi:10.1029/2005JD005776, 2005.

Hansen, J., Sato, M., Ruedy R., et al.: Climate simulations for 1880-2003 with GISS modelE, Clim. Dynam., doi:10.1007/s00382-007-0255-8, 2007.

Harper, L. A., Denmead, O. T., Freney, J. R., and Byers, F. M.: Direct measurements of methane emissions from grazing and feedlot cattle, J. Anim. Sci., 77, 1392-1401, 1999.

Houweling, S., Kaminski, T., Dentener, F., Lelieveld, J., and Heimann, M.: Inverse modeling of methane sources and sinks using the adjoint of a global transport model, J. Geophys. Res., 104, 26 137-26 160, 1999.

Huang Y., Sass, R. L., and Fisher, F. M.: A semi-empirical model of methane emission from flooded rice paddy soils, Global Change
Biol., 4, 247-268, 1998.

IPCC (Intergovernmental Panel on Climate Change): Radiative forcing of climate change, in: Climate Change 2001, Cambridge Univ. Press, New York, Cambridge University Press, 2001.

IPCC (Intergovernmental Panel on Climate Change): Summary for Policymakers, Contribution of Working Group I to the 4th Assessment Report, 2007.

Iversen, T. and Joranger, E.: Arctic air pollution and large scale atmospheric flows, Atmos. Environ., 19, 2099-2108, 1995.

Jacobson, J. Z.: Climate response of fossil fuel and biofuel soot, accounting for soot's feedback to snow and sea ice albedo and emissivity, J. Geophys. Res., 109, D21201, doi:10.1029/2004JD004945, 2004.

Johnson, D., Johnson, K., Ward, G. M., and Branine, M.: Ruminants and other animals, in: Atmospheric methane: Its role in the global environment, edited by: Khalil, M., Springer-Verlag, New York, NY, 112-133, 2000.

Kasischke, E. S., Hyer, E. J., Novelli, P. C., Bruhwiler, P., French, N., Sukhinen, A. I., Hewson, J. H., and Stocks, B. J.: Influences of boreal fire emissions on Northern Hemisphere atmospheric carbon and carbon monoxide, Global Biogeochem. Cy., 19, GB1012, doi:10.1029/2004GB002300, 2005.

Kiehl, J. T.: Twentieth century climate model response and climate sensitivity, Geophys. Res., Lett., 34, L22710, doi:10.1029/2007GL031383, 2007.

Kiehl, J. T., Shields, C.A., Hack, J. J., and Collins, W.: The climate sensitivity of the Community Climate System Model: CCSM3, J. Climate, 19, 2854-2596, 2006.

Kirchgessner, D. A., Piccot, S. D., and Winkler, J. D.: Estimate of global methane emissions from coal mines, Chemosphere, 26, 453-472, 1993.

Klonecki, A., Hess, P., Emmons, L., Smith, L., Orlando, J., and Blake, D.: Seasonal changes in the transport of pollutants into the Arctic troposphere - Model study, J. Geophys. Res., 108(D4), 8367, doi:10.1029/2002JD002199, 2003.

Koch, D. and Hansen, J.: Distant origins of Arctic black carbon: A Goddard Institute for Space Studies ModelE experiment, J. Geophys. Res., 110, D04204, doi:10.1029/2004JD005296, 2005.

Koch, D., Bond, T. C., Streets, D., Unger, N., and van der Werf, G. R.: Global impacts of aerosols from particular source regions and sectors, J. Geophys. Res., 112, D02205, doi:10.1029/2005JD007024, 2007.

Korontzi, S., McCarty, J., Loboda, T., Kumar, S., and Justice, C.: Global distribution of agricultural fires in croplands from 3 years of Moderate Resolution Imaging Spectroradiometer (MODIS) data, Global Biogeochem. Cy., 20, GB2021, doi:10.1029/2005GB002529, 2006.

Lubin, D. and Vogelmann, A. M.: A climatologically significant aerosol longwave indirect effect in the Arctic, Nature, 439, 453456, 2006.

Lubin, D. and Vogelmann, A. M.: Expected magnitude of the aerosol shortwave indirect effect in springtime Arctic liquid water clouds, Geophys. Res. Lett., 34, L11801, doi:10.1029/2006GL028750, 2007.

MacCraken, M. C., Cess, R. D., and Potter, G. L.: Climatic effects of anthropogenic Arctic aerosols: an illustration of climatic feedback mechanisms with one- and two-dimensional climate models, J. Geophys. Res., 91, 14 445-14 450, 1986.

McConnell, J. R., Edwards, R., Kok, G. L., et al.: 20th century 
industrial black carbon emissions altered Arctic climate forcing, Science, 317, 1381-1384, 2007.

Menon, S. and Rotstayn, L.: The radiative influence of aerosol effects on liquid-phase cumulus and stratiform clouds based on sensitivity studies with two climate models, Clim. Dynam., 27, 345-356, 2006.

National Snow and Ice Data Center (NSIDC): Arctic sea ice shatters all previous record lows, NSIDC Arctic Sea Ice News Fall 2007, 1 October 2007.

Nakano, T., Kuniyoshi, S., and Fukuda, M.: Temporal variation in methane emission from tundra wetlands in a permafrost area, northeaster Siberia, Atmos. Environ., 34, 1205-1213, 2000.

Oltmans, S. J., Galbally, I. E., Brunke, E. G., et al.: Trends of ozone in the troposphere, Geophys. Res. Lett, 25, 139-142, 1998.

Petit, J., Jouzel, J., Raynaud, D., et al.: Climate and atmospheric history of the past 420,000 years from the Vostok ice core, Antarctica, Nature, 399, 429-436, 1999.

Prinn, R. G., Weiss, R. F., Miller, B. R., et al.: Atmospheric trends and lifetime of $\mathrm{CH}_{3} \mathrm{CCl}_{3}$ and global $\mathrm{OH}$ concentrations, Science, 269, 187-189, 1995.

Pueschel, R. F. and Kinne, S. A.: Physical and radiative properties of Arctic atmospheric aerosols, Sci. Total Env., 161, 811-824, 1995.

Quinn, P. K., Shaw, G., Andrews, E., Dutton, E. G., Ruoho-Airola, T., Gong, S. L.: Arctic Haze: Current trends and knowledge gaps, Tellus, 59B, 99-114, 2007.

Ritter, C., Notholt, J., Fisher, J., and Rathke, C.: Direct thermal radiative forcing of tropospheric aerosol in the Arctic measured by ground based infrared spectrometry, Geophys. Res. Lett., 32, L23816, doi:10.1029/2005GL024331, 2005.

Schulz, M., Textor, C., and Kinne, S., et al.: Radiative forcing by aerosols as derived from the AeroCom present-day and pre-industrial simulations, Atmos. Chem. Phys., 6, 5255-5264, 2006,

http://www.atmos-chem-phys.net/6/5255/2006/.

Seinfeld, J. H.: Ozone air quality models: A critical review, J. Air Pollut. Control Assoc., 38, 616-645, 1988.

Serreze, M. C., Holland, M. M., and Stroeve, J.: Perspectives on the Arctic's shrinking sea-ice cover, Science, 315, 1533-1536, 2007.

Sharma, S., Andrews, E., Barrie, L. A., Ogren, J. A., and Lavoue, D.: Variations and sources of the equivalent black carbon in the High Arctic revealed by long term observations at Alert and Barrow: 1989-2003, J. Geophys. Res., 11, D14208, doi:10.1029/2005JF006581, 2006.

Shaw, G. E.: Eddy diffusion transport of Arctic pollution from the mid-latitudes: a preliminary model, Atmos. Environ., 15, 14831490, 1981.

Shaw, G. E.: The Arctic haze phenomenon, B. Am. Meteorol. Soc., 76, 2403-2413, 1995.

Shaw, G. E. and Stamnes, K.: Arctic haze: perturbation of the polar radiation budget, Am. N.Y. Acad. Sci., 338, 533-539, 1980.

Shindell, D.: Local and remote contributions to Arctic warming, Geophys. Res. Lett., 34, L14704, doi:10.1029/2007GL030221, 2007.

Shindell, D. T., Faluvegi, G., and Bell, N.: Preindustrial-to-presentday radiative forcing by tropospheric ozone from improved simulations with the GISS chemistry-climate GCM, Atmos. Chem. Phys., 3, 1675-1702, 2003,

http://www.atmos-chem-phys.net/3/1675/2003/.
Shindell, D., Faluvegi, G., Lacis, A., Hansen, J., Ruedy, R., and Aguilar, E.: Role of tropospheric ozone increases in $20^{t h}$-century climate change, J. Geophys. Res., 111, D08302, doi:10.1029/2005JD006348, 2006.

Sirois, A. and Barrie, L. A.: Arctic lower tropospheric aerosol trends and composition at Alert, Canada: 1980-1995, J. Geophys. Res., 104, 11 599-11 618, 1999.

Smol, J. P., Wolfe, A. P., Birks, H. J. B., et al.: Climate-driven regime shifts in the biological communities of Arctic lakes, Proc. Nat. Acad. Sci., 102, 4397-4402, 2005.

Spahni, R., Chappellaz, J., Stocker, T. F., et al.: Atmospheric methane and nitrous oxide of the late Pleistocene from Antarctic ice cores, Science, 310, 1317-1321, 2005.

Stohl, A.: Characteristics of atmospheric transport into the Arctic troposphere, J. Geophys. Res., 111, D11306, doi:10.1029/2005JD006888, 2006.

Stohl, A., Andrews, E., Burkhart, J. F., Forster, C., Herber, A., Hoch, S. W., Kowal, D., Lunder, C., Mefford, T., Ogren, J. A., Sharma, S., Spichtinger, N., Stebel, K., Stone, R., Ström, J., Tørseth, K., Wehrli, C., and Yttri, K. E.: Pan-Arctic enhancements of light absorbing aerosol concentrations due to North American boreal forest fires during summer 2004, J. Geophys. Res., 111, D22214, doi:10.1029/2006JD007216, 2006.

Stohl, A., Berg, T., Burkhart, J. F., et al.: Arctic smoke - record high air pollution levels in the European Arctic due to agricultural fires in Eastern Europe in spring 2006, Atmos. Chem. Phys., 7, 511 534, 2007, http://www.atmos-chem-phys.net/7/511/2007/.

Stroeve, J. C., Markus, T., Meier, W. N., and Miller, J.: Recent changes in the Arctic melt season, Ann. Glaciol., 44, 367-374, 2006.

Textor, C., Schulz, M., Guibert, S., et al.: The effect of harmonized emissions on aerosol properties in global models - an AeroCom experiment, Atmos. Chem. Phys., 7, 4489-4501, 2007, http://www.atmos-chem-phys.net/7/4489/2007/.

Textor, C., Schulz, M., Guibert, S., et al.: Analysis and quantification of the diversities of aerosol life cycles within AeroCom, Atmos. Chem. Phys., 6, 1777-1813, 2006,

http://www.atmos-chem-phys.net/6/1777/2006/.

Twomey, S.: The influence of pollution on the shortwave albedo of clouds, J. Atmos. Sci., 34, 1149-1152, 1977.

US EPA: Automobiles and Carbon Monoxide, EPA 400-F-92-005, 1993.

US EPA: VOCs Controls, EPA/452/B-02-001, 1999.

US EPA: Global Mitigation of Non- CO2 Greenhouse Gases, EPA 430-R-06-005, 2006.

Walter, K. M., Zimov, S. A., Chanton, J. P., Verbyla, D., and Chapin III, F. S.: Methane bubbling from Siberian thaw lakes as a positive feedback to climate warming, Nature, 443, 71-75, 2006.

Warren, S. G. and Wiscombe, W. J.: Dirty snow after nuclear war, Nature, 313, 467-470, 1985.

Wuebbles, D. J. and Hayhoe, K.: Atmospheric methane and global change, Earth-Sci. Rev., 57, 177-210, 2002.

Zimov, S. A., Schuur, E. A. G., and Chapin III, F. S.: Climate change: Permafrost and the global carbon budget, Science, 312, 1612-1613, 2006.

Zwally, H. J., Abdalati, W., Herring, T., Larson, K., Saba, J., and Steffen, K.: Surface melt-induced acceleration of Greenland icesheet flow, Science, 297, 218-222, 2002. 